\title{
Pengaruh Profitabilitas, Resiko Keuangan dan Pertumbuhan Perusahaan terhadap Manajemen Laba pada Perusahaan Kosmetik dan Keperluan Rumah Tangga yang Terdaftar di Bursa Efek Indonesia Tahun 2013-2017
}

\author{
Rina Dwiarti ${ }^{1 *}$, Anna Nubua Hasibuan ${ }^{2)}$ \\ ${ }^{12)}$ Fakultas Ekonomi, Universitas Mercu Buana Yogyakarta \\ e-mail: annanubuahsb97@gmail.com ${ }^{1 *}$
}

\begin{abstract}
This study aims to identify and analyze the effect of profitability, financial risk and growth on earnings management in cosmetics and household needs companies listed on the Indonesia Stock Exchange (IDX) in 2013-2017. The population used in this study are 6 companies listed on the Indonesia Stock Exchange. The process of determining the sample in this study using purposive sampling so that the number of samples obtained by 5 companies cosmetics and household needs. The type of data used in the research ii is secondary data sourced from the Indonesia Stock Exchange and the analysis technique uses multiple linear regression analysis. The results of this study indicate that partially profitability variables have a negative and not significantly effect on earnings management. Financial risk variables have a negative and not significantly effect on earnings management. The company's growth variable has a negative and not significantly effect on earnings management. The results of the study show that simultaneously the variable profitability, financial risk and company growth have no effect on earnings management.
\end{abstract}

Keyword: Profitability, Financial Risk, Company Growth, Profit Management

\section{PENDAHULUAN}

Dalam laporan keuangan, laba adalah salah satu indikator yang digunakan untuk menaksir kinerja manajemen. Informasi laba sering menjadi target rekayasa tindakan oportunis manajemen untuk memaksiumkan keputusannya. Tindakan oportunis tersebut dilakukan dengan cara memilih kebijakan akuntansi tertentu, sehinga laba perusahaan dapat diatur, dinaikkan maupun diturunkan sesuai dengan keinginannya. Perilaku manajemen untuk mengatur laba sesuai dengan keinginannya ini dikenal istilah manajemen laba (earnings management).

Ada beberapa faktor pendorong manajer dalam melakukan manajemen laba, diantaranya adalah profitabilitas, leverage dan pertumbuhan perusahaan. Profitabilitas menggambarkan kemampuan perusahaan dalam menghasilkan laba selama satu periode waktu tertentu. Pada umumnya nilai profitabilitas suatu perusahaan dapat digunakan sebagai indikator untuk mengukur kinerja suatu perusahaan. Semakin tinggi profitabilitas suatu perusahaan maka kemampuan perusahaan dalam menghasilkan laba juga meningkat. Keterkaitan antara profitabilitas yang diperoleh perusahaan kecil pada periode waktu tertentu akan memicu perusahaan untuk melakukan manajemen laba dengan cara meningkatkan laba dan pendapatan yang diperoleh sehingga akan memperlihatkan saham dan mempertahankan investor yang ada. 
Profitabilitas adalah kemampuan perusahaan memperoleh laba dalam hubungannya dengan penjualan, total aktiva, maupun modal sendiri (Agus, 2011). Sedangkan menurut Fatmasari (2016), menyatakan bahwa profitabilitas menggambarkan kemampuan perusahaan menghasilkan laba untuk periode tertentu. Profitabilitas suatu perusahaan diukur dari kemampuan perusahaan menggunakan aktivanya secara produktif, dengan jumlah aktiva perusahaan tersebut. Perusahaan berjalan dengan baik, sedangkan apabila tingkat profitabilitas yang rendah menunjukkan bahwa kinerja dari suatu perusahaan kurang baik dan akibatnya kinerja yang dilakukan oleh manajer tampak buruk dimata investor.

Variabel berikutnya yang akan diteliti dalam penelitian ini adalah leverage. Leverage adalah penggunaan aset dan sumber dana oleh perusahaan yang memilki biaya (beban tetap) dengan maksud agar meningkatkan keuntungan potensial pemegang saham (Sartono, 2008 dalam Novianus, 2016). Perusahaan dengan tingkat leverage yang tinggi termotivasi untuk melakukan manajemen laba agar terhindar dari pelanggaran hutang.

Faktor lain yang berhubungan dengan manajemen laba yaitu pertumbuhan perusahaan. Pertumbuhan perusahaan merupakan nilai yang menunjukkan besar kecilnya perusahaan. Investor dalam menanam modal yang ditanamkan artinya memperoleh hasil yang menguntungkan. Namun perusahaan besar cenderung menjaga laporan posisi keuangannya dala keadaan tertentu sehingga kinerjanya tidak terlalu baik, dengan menyajikan laba yang lebih rendah dari nilai yang sebenarnya terutama selama periode kemakmuran tinggi.

Menurut Izzati dan Sari (2013), memaparkan bahwa perusahaan yang memilki pendapatan yang tinggi, kemungkinan tidak termotivasi dalam melakukan tindakan manipulasi laba. Sebaliknya jika perusahaan memilki pertumbuhan pendapatan rendah, maka akan memiliki kecenderungan untuk menyesatkan laporan laba atau perubahan laba melalui tindakan manipulasi laba. Dengan demikian, tinggi rendahnya pertumbuhan pendapatan menjadi sumber variasi tindakan manajemen laba. Pernyataan tersebut sesuai dengan hasil penelitian Fricilia dan Lukman (2015) yang berhasil membuktikan bahwa adanya pengaruh pertumbuhan perusahaan terhadap manajemen laba.

Anshori, Rosyidah dan Wahidahwati (2014) menyatakan bahwa pertumbuhan suatu perusahaan dalam sudut pandang investor merupakan suatu tanda perusahaan memiliki aspek yang menguntungkan sehingga pihak manajer berusaha untuk menunjukkan bahwa perusahaan telah bertumbuh dengan baik. Sebagaimana telah dijelaskan sebelumnya bahwa investor hanya berminat pada perusahaan yang bertumbuh positif secara berkelanjutan. Pengetahuan tersebut mendorong manajer pada perusahaan yang pertumbuhan penjualannya tidak stabil, untuk melakukan manajemen laba. Hal tersebut mengindikasikan bahwa untuk menjaga produktivitas dan menarik minat investor perlu dilakukannya manajemen laba. Penelitian ini dilakukan dengan tujuan:

1. Untuk menguji pengaruh profitabilitas terhadap manajemen laba pada perusahaan Kosmetik dan Keperluan Rumah Tangga yang terdaftar di BEI periode tahun 2013-2017. 
2. Untuk menguji pengaruh resiko keuangan terhadap manajemen laba pada perusahaan Kosmetik dan Keperluan Rumah Tangga yang terdaftar di BEI periode tahun 2013-2017.

3. Untuk menguji pengaruh pertumbuhan perusahaan terhadap manajemen laba pada perusahaan Kosmetik dan Keperluan Rumah Tangga yang terdaftar di BEI periode tahun 2013-2017.

4. Untuk menguji pengaruh profitabilitas, resiko keuangan dan pertumbuhan perusahaan berpengaruh secara simultan terhadap manajemen laba pada perusahaan Kosmetik dan Keperluan Rumah Tangga yang terdaftar di BEI periode tahun 2013-2017.

\section{TINJAUAN PUSTAKA}

\section{Profitabilitas}

Profitabilitas adalah kemampuan perusahaan dalam mencari keuntungan (Kasmir, 2016). Rasio ini juga memberikan ukuran tingkat efektivitas manajemen suatu perusahaan. Hal ini ditunjukkan oleh laba yang dihasilkan dari penjualan dan pendapatan investasi. Pada umumnya nilai profitabilitas suatu perusahaan dapat digunakan sebagai indikator untuk mengukur kinerja suatu perusahaan. Semakin tinggi profitabilitas dengan manajemen laba adalah ketika profitabilitas yang diperoleh perusahaan kecil pada periode waktu tertentu akan memicu perusahaan untuk melakukan manajemen laba dengan cara meningkatkan pendapatan yang diperoleh sehingga akan memperlihatkan saham dan mempertahankan investor yang ada.

Menurut Riyanto (2011), menyatakan bahwa profitabilitas merupakan rasio yang menghubungkan laba dari penjualan dan investasi. Macam-macam rasio profitabilitas antara lain:

1. Profitabilitas dalam kaitannya dengan penjualan menggunakan rasio margin laba kotor dan margin laba bersih.

2. Profitabilitas dalam hubungannya dengan investasi, menggunakan dua pengukuran yaitu ROI (Return On Investment) dan ROA (Return On Asset) dimana ROA digunakan untuk mengukur efektivitas perusahaan dalam menghasilkan keuntungan dengan memanfaatkan aktiva yang dimilikinya.

Profitabilitas suatu kemampuan perusahaan dalam menghasilkan laba dalam suatu periode tertentu. Untuk mengukur tingkat profitabilitas dalam pengukuran ini, digunakan rasio ROA (Return On Asset). Diukur dengan rumus sebagai berikut:

$$
\mathrm{ROA}=\frac{\text { Laba setelah pajak }}{\text { Total } \text { Aset }} \mathrm{X} 100 \%
$$

\section{Resiko Keuangan}

Leverage (resiko keuangan) adalah pengunaan aset dan sumber dana oleh perusahaan yang memiliki biaya (beban tetap) dengan maksud agar meningkat keuntungan potensial pemegang saham (Sartono, 2008 dalam Novianus, 2016). Leverage digunakan untuk mengukur kemampuan perusahaan dalam menjamin seluruh hutangnya dengan seluruh modal yang dimiliki perusahaan. Perusahaan 
dengan tingkat leverage yang tinggi termotivasi untuk melakukan manajemen laba agar terhindar dari pelanggaran hutang. Widyaningdyah (2011), menjelaskan bahwa perusahaan yang mempunyai rasio leverage tinggi akibat besarnya jumlah hutang dibandingkan dengan aktiva yang dimiliki perusahaan, diduga melakukan manejemen laba karena perusahaan terancam deflaut yaitu tidak dapat memenuhi kewajiban pembayaran hutang pada waktunya.

Menurut Riyanto (2011), rasio leverage merupakan rasio yang digunakan perusahaan agar dapat menilai sejauh mana perusahaan menggunakan uang yang dipinjam. Rasio-rasio yang terdapat pada rasio leverage antara lain:

1. Rasio utang terhadap ekuitas

Menunjukkan seberapa return yang akan diberikan perusahaan untuk para pemegang saham.

2. Rasio utang terhadap total aktiva

Rasio ini menekankan pada peran penting pendanaan utang bagi perusahaan dengan menunjukkan persentase aktiva perusahaan dimulai oleh pendanaan utang.

3. Rasio utang terhadap total aktiva

Rasio ini memberitahu kita proporsi relative kontribusi oleh kreditor dan oleh pemilik. Adapun rumus resiko keuangan dalam penelitian ini adalah:

$$
\text { Resiko keuangan }=\frac{\text { Total Utang }}{\text { Total Aset }}
$$

\section{Pertumbuhan Perusahaan}

Pertumbuhan perusahaan merupakan tahap dimana perusahaan telah memperoleh pangsa pasar dan mengalami peningkatan penjualan. Perusahaan juga mulai melakukan diversifikasi lini produk. Laba perusahaan sudah lebih besar dibandingkan dengan laba pada tahun sebelumnya. Fokus perusahaan adalah meningkatkan pangsa pasar yang telah dimiliki.

Diperlukan keseimbangan antara laba dan asset, dan pertumbuhan. Ketidakseimbangan antara faktor-faktor tersebut akan berdampak besar pada arus kas. Perusahaan yang sangat membutuhkan asset dan sedang berkembang dengan pesat akan membutuhkan dana yang subtansial guna menjaga neracanya dalam kondisi baik. Dana tersebut dapat diperoleh dari internal atau eksternal perusahaan (Muhammadinah, 2016). Perusahaan mempunyai kewajiban membayar sejumlah pajak yang sebenarnya ditentukan dengan menggunakan laba sebagai dasar perhitunganya. Semakin besar laba perusahaan maka pajak yang harus dibayar juga semakin besar. Peningkatan pertumbuhan perusahaan akan diikuti dengan peningkatan laba yang dilaporkan.

Adapun rumus pengukuran pertumbuhan perusahaan dalam penelitian ini adalah:

$$
\text { Pertumbuhan Perusahaan }=\frac{\text { Total Asset }_{t}-\text { Total Asset }_{t-1}}{\text { Total Asset }_{t-1}}
$$


Keterangan:

Total Asset $t_{t}$ : Total harta yang dimiliki perusahaan tahun sekarang.

TotalAssett-1 : Total harta yang dimili perusahaan tahun sebelumnya.

\section{Manajemen Laba}

Scott (2015) menyatakan bahwa manajemen laba adalah pilihan yang dilakukan oleh manajer dalam menentukan kebijakan akuntansi, atau aksi nyata, yang mempengaruhi laba sehingga mencapai sasaran dengan melaporkan laba tertentu. Menurut Rosenzweig (1995) dalam (Sri, 2008), manajemen laba adalah tindakan manajer untuk menaikkan (menurunkan) laba periode berjalan dari sebuah perusahaan yang dikelolanya tanpa menyebabkan kenaikan (penurunan) keuntungan ekonomi perusahaan jangka panjang.

Pada penelitian ini menggunakan rumus manajemen laba menggunakan model McNichols (2000) sebagai berikut:

Keterangan:

$$
\text { Manajemen Laba }(M L)=\frac{\text { Akrual Modal Kerja }(t)}{\text { Pendapatan periode }(t)}
$$

Akrual modal Kerja $=\Delta \mathrm{AL}-\Delta \mathrm{HL}-\Delta \mathrm{Kas}$

$\Delta \mathrm{AL} \quad$ : Perubahan aktiva lancar pada periode $\mathrm{t}$

$\Delta \mathrm{HL} \quad$ : Perubahan hutang lancar pada periode $\mathrm{t}$

$\Delta$ Kas : Perubahan kas dan ekuivalen kas periode $\mathrm{t}$

\section{Kerangka Pemikiran}

Dengan demikian kerangka pemikiran beberapa pengaruh profitabilitas, resiko keuangan dan pertumbuhan perusahaan terhadap manajemen laba digambarkan sebagai berikut:

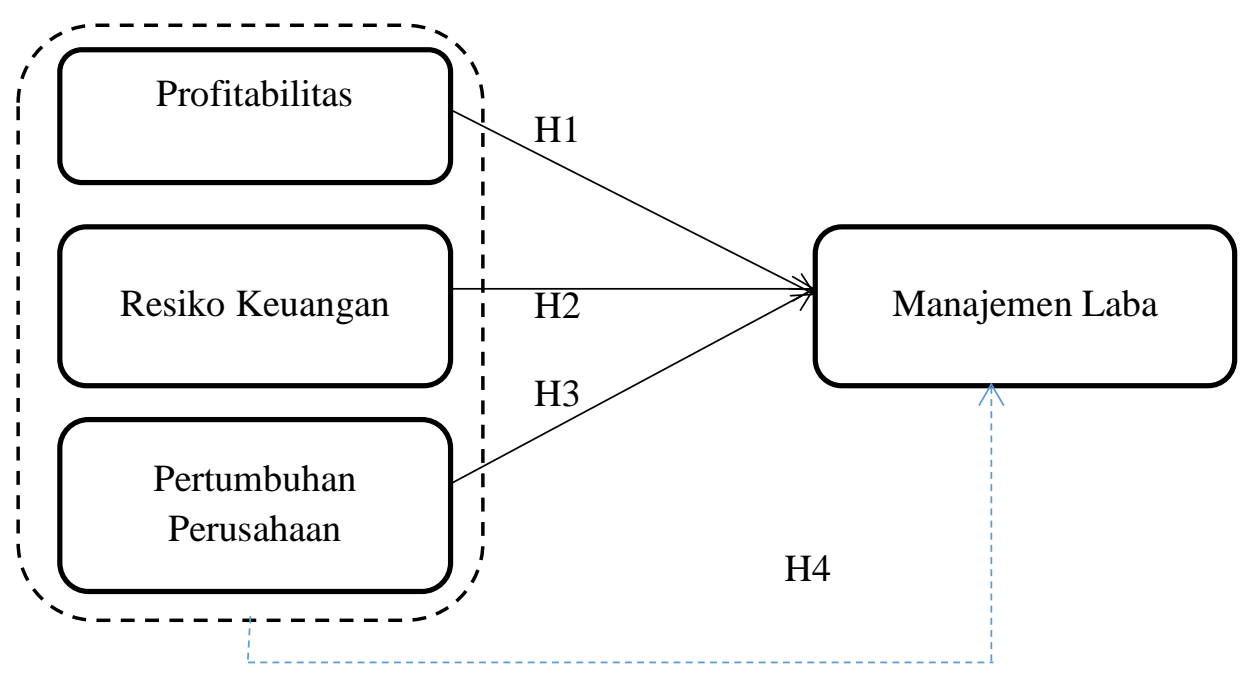

Gambar 1. Kerangka Pemikiran

Rina, Anna: Pengaruh Profitabilitas, Resiko Keuamgan dan Pertumbuhan Perusahaan terhadap Manajemen Laba pada . 
Keterangan:

$$
\begin{aligned}
& \longrightarrow \text { : Pengaruh Variabel X terhadap Y secara Parsial } \\
& \rightarrow \text { : Pengaruh Variabel X terhadap Y secara Simultan }
\end{aligned}
$$

\section{Hipotesis}

$\mathrm{Ha}_{1} \quad$ : Profitabilitas berpengaruh terhadap manajemen laba.

$\mathrm{Ha}_{2} \quad$ : Resiko keuangan berpengaruh terhadap manajemen laba.

$\mathrm{Ha}_{3}$ : Pertumbuhan perusahaan berpengaruh terhadap manajemen laba.

$\mathrm{Ha}_{4}$ : Profitabilitas, resiko keuangan dan pertumbuhan perusahaan terhadap manajemen laba.

\section{METODE PENELITIAN}

\section{Populasi dan Sampel Penelitian}

Populasi yang digunakan dalam penelitian ini adalah perusahaan Kosmetik dan Keperluan rumah Tangga yang terdaftar di pada Bursa Efek Indonesia yaitu sebanyak 6 perusahaan. Proses penentuan sampel dalam penelitian ini menggunakan teknik purposive sampling. Adapun perusahaan sektor perusahaan Kosmetik dan Keperluan Rumah Tangga yang dipilih didasarkan atas kriteria sebagai berikut:

1. Perusahaan Kosmetik dan Keperluan Rumah Tangga yang terdaftar di Bursa Efek Indonesia (BEI) selama periode 2013-2017.

2. Perusahaan yang menerbitkan laporan keuangan yang telah diaudit untuk periode yang berakhir 31 Desember 2013-2017.

3. Perusahaan memiliki kelengkapan data mengenai variabel-variabel yang diteliti selama periode pengamatan.

4. Perusahaan tidak melakukan perubahan bisnis atau perpindahan sektor selama periode 2013-2017.

Berdasarkan kriteria yang telah ditetapkan tersebut diatas, maka jumlah perusahaan sektor perusahaan Kosmetik dan Keperluan Rumah Tangga yang terdaftar di Bursa Efek Indonesia yang dijadikan sampel dalam penelitian ini adalah sebanyak 5 perusahaan yang meliputi:

Tabel 1. Sampel Penelitian

\begin{tabular}{clll}
\hline NO. & Kode Saham & \multicolumn{1}{c}{ Nama } & \multicolumn{1}{c}{ Tanggal IPO } \\
\hline 1. & ADES & $\begin{array}{l}\text { Akasha Wira International Tbk, PT (d.h Ades } \\
\text { Waters Indonesia Tbk, PT) }\end{array}$ & 13-Jun-1994 \\
2. & MBTO & Martina Berto Tbk & 13-Jan-2011 \\
3. & MRAT & Mustika Ratu Tbk & 27-Jul-1995 \\
4. & TCID & Mandom Indonesia Tbk & 23-Sep-1993 \\
5. & UNVR & Unilever Indonesia Tbk & 11-Jan-1982 \\
\hline
\end{tabular}

\section{Jenis dan Sumber Data}

Jenis data yang digunakan adalah data sekunder dari perusahaan Kosmetik dan Keperluan Rumah Tangga yang terdaftar pada Bursa Efek Indonesia (BEI), yaitu laporan tahunan perusahaan 
yang go public tercatat periode 2013-2017. Data tersebut diperoleh dengan mengakses situs di Bursa Efek Indonesia (www.idx.co.id).

\section{Metode Pengumpulan Data}

Metode pengumpulan data yang digunakan adalah studi pustaka dan studi dokumentasi. Studi pustaka dilakukan dengan mengolah data , artikel, jurnal maupun media tertulis lain yang berkaitan dengan topik pembahasan dari penelitian ini. Studi dokumentasi adalah metode pengumpulan data dengan menggunakan data sekunder yang digunakan untuk menyelesaikan masalah dalam penelitian ini seperti laporan tahunan perusahaan yang menjadi sampel penelitian.

\section{Teknik Analisis Data}

Penelitian ini menggunakan metode penelitian kuantitatif dengan regresi linier berganda. Adapun persamaan regresi linier berganda yaitu: $\mathrm{Y}=\mathrm{a}+\mathrm{bX}+\mathrm{bX}_{2}+\mathrm{bX}_{3}+\mathrm{e}$

Dimana :

$\mathrm{Y} \quad=$ Manajemen Laba

$\mathrm{a} \quad=$ Konstanta

b = Koefisien Regresi

$\mathrm{X}_{1} \quad=$ Profitabilitas

$\mathrm{X}_{2} \quad=$ Resiko Keuangan

$\mathrm{X}_{3} \quad=$ Pertumbuhan Perusahaan

$\mathrm{e} \quad=$ Standar Eror

\section{HASIL DAN PEMBAHASAN}

\section{Uji Asumsi Klasik}

1. Uji Normalitas

Analisis ini menggunakan analisis regresi linier dengan syarat model regresi yang baik adalah distribusi data masing-masing variabel yang normal atau mendekati normal. Pengujian normalitas dilakukan dengan Uji Kolmogorov - Smirnov yang dilakukan terhadap nilai residual.

Tabel 2. Uji Normalitas One-Sampel Kolmogorov-Smirnov

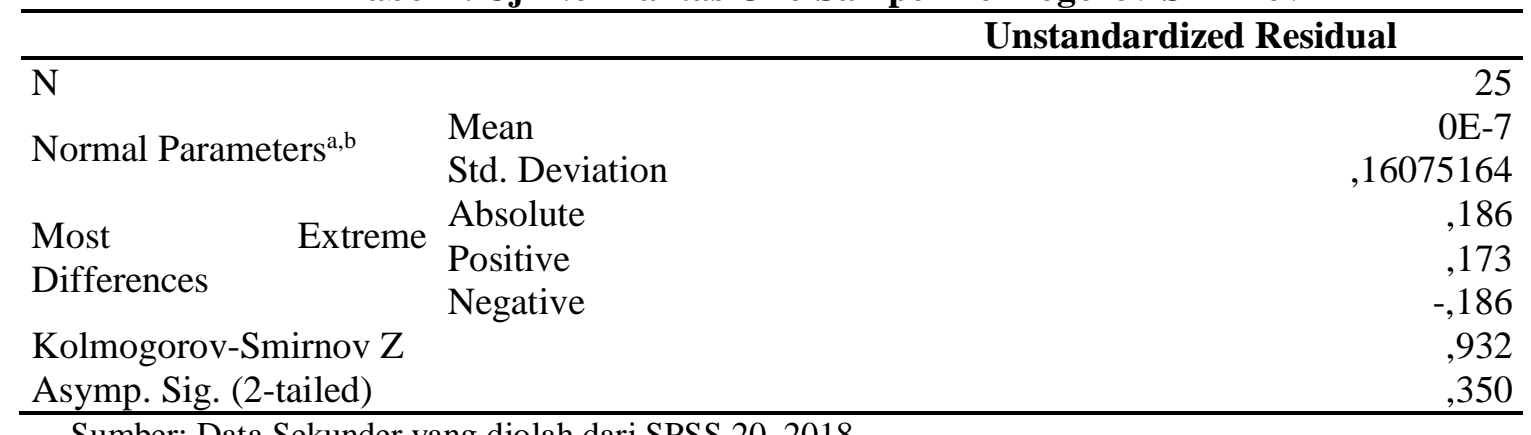

Sumber: Data Sekunder yang diolah dari SPSS 20, 2018 
Berdasarkan hasil uji normalitas menggunakan Kolmogorov-Smirnov pada Tabel 2. menunjukkan bahwa nilai signifikan sebesar 0,350 lebih besar dari pada $\alpha(0,350>0,05)$. Sehingga dapat disimpulkan bahwa data dalam penelitian ini berdistribusi normal.

\section{Uji Multikolinearitas}

Uji multikolinearitas bertujuan untuk menguji apakah model regresi ditemukan adanya korelasi antara variabel bebas. Model regresi yang baik seharusnya tidak terjadi korelasi diantara variabel independen. Multikolinearitas dapat dilihat dari nilai tolerance dan Variance Inflation Factor (VIF). Nilai yang umum dipakai untuk menunjukkan adanya multikolinearitas adalah nilai tolerance < 0,10 atau sama dengan nilai VIF > 10 (Ghozali, 2001). Nilai tolerance dan Variance Inflation Factor (VIF) yang terdapat pada masing-masing variabel pada penelitian ini seperti terlihat pada tabel berikut:

Tabel 3. Uji Multikolinearitas

\begin{tabular}{|c|c|c|c|}
\hline \multirow{2}{*}{\multicolumn{2}{|c|}{ Model }} & \multicolumn{2}{|c|}{ Collinearity Statistics } \\
\hline & & Tolerance & VIF \\
\hline \multirow{4}{*}{1} & (Constant) & & \\
\hline & Profitabilitas & ,794 & 1,260 \\
\hline & Resiko Keuangan & 811 & 1,234 \\
\hline & Pertumbuhan Perusahaan & 959 & 1,042 \\
\hline
\end{tabular}

Sumber: Data Sekunder yang diolah dari SPSS 20, 2018

Suatu model regresi dinyatakan model bebas dari multikolinearitas adalah jika mempunyai nilai VIF dibawah 10. Dari Tabel 3. diperoleh bahwa semua variabel bebas memiliki nilai VIF berada di bawah angka 10. Dengan demikian diperoleh tidak adanya masalah multikolinearitas dalam model regresi.

\section{Uji Autokorelasi}

Uji autokolerasi bertujuan untuk menguji apakah dalam model regresi linier ada kolerasi antara kesalahan penganggu pada periode t-1 9 (sebelumnya). Menurut Ghozali (2009), model regresi yang baik adalah regresi yang bebas dari autokolerasi. Untuk mengetahui ada tidaknya autokolerasi c dapat melihat nilai uji D-W dengan ketentuan sebagai berikut:

Tabel 4. Uji Autokorelasi

Model Summary (b)

\begin{tabular}{rrrrrr}
\hline Model & R & R Square & Adjusted R Square & Std. Error of the Estimate & $\begin{array}{l}\text { Durbin- } \\
\text { Watson }\end{array}$ \\
\hline 1 &, $118^{\mathrm{a}}$ &, 014 &,- 127 &, 1718507 & 2,452 \\
\hline
\end{tabular}

Sumber: Data Sekunder yang diolah dari SPSS 20, 2018

Berdasarkan Tabel 4. hasil nilai yang didapatkan adalah 2,452. Dengan n:25, k: 3 dL: Sedangkan b besarnya DW-tabel adalah dl (batas luar) $=1,1228$; du (batas dalam) $=1,6540$; nilai 4-dL= 1,1224; nilai 4-du = 1,6536. 
Tabel 5. Hasil Uji Autokorelasi Runs Test

\begin{tabular}{lr}
\hline Test Value ${ }^{\mathrm{a}}$ &, 00889 \\
Cases $<$ Test Value & 12 \\
Cases $>=$ Test Value & 13 \\
Total Cases & 25 \\
Number of Runs & 16 \\
Z &, 827 \\
Asymp. Sig. (2-tailed) &, 408 \\
\hline
\end{tabular}

a. Median

Sumber: Data Sekunder yang diolah dari SPSS 20, 2018

4. Uji Heteroskedastisitas

Uji heterokedastisitas bertujuan menguji apakah dalam sebuah model regresi terjadi ketidaksamaan variance dari residual atau pengamatan satu ke pengamatan yang lain. Cara mendeteksi ada atau tidaknya heterokedastisitas salah satunya adalah dengan uji Glejser.

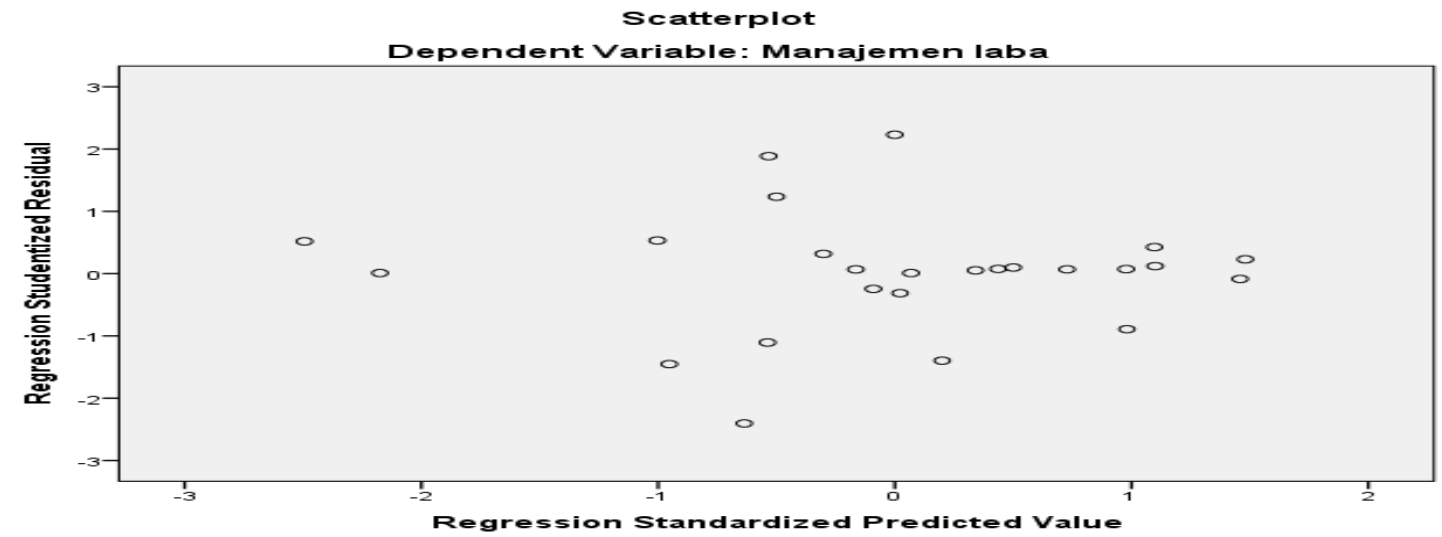

Gambar 2. Hasil Uji Heteroskedastisitas

Hasil dari uji heteroskedastisitas di atas, menunjukkan bahwa titik-titik data menyebar diatas dan dibawah atau disekitar angka 0 sumbu Y. Titik-titik tidak mengumpul hanya diatas atau dibawah saja. Penyebaran titik-titik data tidak adanya membentuk pola bergelombang melebar kemudian menyempit dan melebar kembali. Jadi dapat disimpulkan bahwa tidak terjadi masalah heteroskedastisitas dalam model regresi.

\section{Uji Regresi Linier Berganda}

Analisis regresi linier berganda digunakan untuk mengetahui pengaruh variabel independen Profitabilitas $\left(\mathrm{X}_{1}\right)$ Resiko Keuangan $\left(\mathrm{X}_{2}\right)$, Pertumbuhan Perusahaan $\left(\mathrm{X}_{3}\right)$, terhadap variabel dependen Manajemen Laba (Y) pada perusahaan Kosmetik dan Keperluan Rumah Tangga yang terdaftar di Bursa Efek Indonesia (BEI) tahun 2013-2017. 
Tabel 6. Hasil Analisis Statistik

\begin{tabular}{|c|c|c|c|}
\hline Variabel & B & $\mathbf{t}$ & Sig. $t$ \\
\hline Konstanta & $-0,008$ & & \\
\hline Profitabilitas & $-5,874 \mathrm{E}-005$ & $-0,023$ & 0,982 \\
\hline Resiko Keuangan & 0,004 & 0,157 & 0,877 \\
\hline Pertumbuhan Perusahaan & $-0,239$ & $-0,525$ & 0,605 \\
\hline Adjusted $R$ Square $=0,076$ & & & \\
\hline F-hitung $\quad=0,098$ & & & \\
\hline$=0,960^{\mathrm{b}}$ & & & \\
\hline
\end{tabular}

Sumber: Data Sekunder yang diolah dari SPSS 20, 2018

Berdasarkan Tabel 6. hasil uji regresi linier berganda digunakan dalam penelitian ini dapat disusun rumus regresi persamaannya sebagai berikut:

$$
\mathrm{Y}=-0,008-5,874 \mathrm{E}-005 \mathrm{X}_{1}+0,004 \mathrm{X}_{2}-0,239 \mathrm{X}_{3}
$$

\section{Uji Hipotesis}

\section{Uji Regresi Parsial (Uji t)}

Uji statistik t pada dasarnya menunjukkan seberapa jauh pengaruh satu variabel independen secara individual dalam menerangkan variasi variabel dependen. Berdasarkan data Tabel 6. dapat diterangkan sebagai berikut:

1. Variabel Profitabilitas

Dari hasil perhitungan analisis data untuk variabel profitabilitas, diperoleh nilai sig 0,982 > 0,05 dan hasil perhitungan pada regresi berganda diperoleh nilai $t_{\text {hitung }}-0,023<$ nilai $t_{\text {tabel }} 2,080$, sehingga dapat disimpulkan bahwa $\mathrm{H}_{\mathrm{o}}$ diterima dan $\mathrm{H}_{\mathrm{a}}$ ditolak artinya variabel profitabilitas tidak berpengaruh dan tidak signifikan terhadap manajemen laba pada perusahaan Kosmetik dan Keperluan Rumah Tangga yang terdaftar di BEI tahun 2013-2017.

2. Variabel Resiko Keuangan

Dari hasil perhitungan analisis data untuk variabel resiko keuangan, diperoleh nilai sig 0,877> 0,05 dan hasil perhitungan pada regresi berganda diperoleh nilai $t_{\text {hitung }} 0,157<$ nilai $t_{\text {tabel }} 2,080$, sehingga dapat disimpulkan bahwa $\mathrm{H}_{\mathrm{o}}$ diterima dan $\mathrm{H}_{\mathrm{a}}$ ditolak artinya variabel resiko keuangan tidak berpengaruh dan tidak signifikan terhadap manajemen laba pada perusahaan Kosmetik dan Keperluan Rumah Tangga yang terdaftar di BEI tahun 2013-2017.

3. Variabel Pertumbuhan Perusahaan

Dari hasil perhitungan analisis data untuk variabel pertumbuhan perusahaan diperoleh nilai sig 0,605 > 0,05 dan hasil perhitungan pada regresi berganda diperoleh nilai thitung $-0,525<$ nilai tabel 2,080, sehingga dapat disimpulkan bahwa $\mathrm{H}_{0}$ diterima dan $\mathrm{H}_{a}$ ditolak yang artinya variabel pertumbuhan perusahaan tidak berpengaruh dan tidak sigifikan terhadap manajemen laba pada perusahaan Kosmetik dan Keperluan Rumah Tangga yang terdaftar di BEI tahun 2013-2017. 


\section{Uji Simultan (Uji F)}

Berdasarkan Tabel 6. hasil analisis data uji F diperoleh sig $0,960^{\mathrm{b}}>0,05$ dan diperoleh nilai Fhitung $0,098<$ nilai $\mathrm{F}_{\text {tabel }}$ 3,0491 sehingga dapat disimpulkan bahwa $\mathrm{H}_{\mathrm{o}}$ ditolak Ha diterima artinya seluruh variabel independen (profitabilitas, resiko keuangan dan pertumbuhan perusahaan) secara bersama-sama tidak berpengaruh terhadap variabel dependen (manajemen laba) pada perusahaan Kosmetik dan Keperluan Rumah Tangga yang terdaftar di BEI tahun 2013-2017.

\section{Uji Koefisien Determinasi (Adjusted R²)}

Berdasarkan Tabel 6. hasil uji koefisien determinasi terlihat bahwa nilai Adjusted R Square sebesar 0,076 yang menunjukkan presentase bahwa berpengaruh independen profitabilitas, resiko keuangan dan pertumbuhan perusahaan terhadap variabel dependen manajemen laba adalah sebesar $7,6 \%$.

\section{Pembahasan}

\section{Pengaruh Profitabilitas terhadap Manajemen Laba}

Pada Tabel 6. Hasil uji parsial secara keseluruhan yaitu tahun 2013-2017, pada variabel independen profitabilitas didapat $t$ hitung sebesar 0,023 lebih kecil dari t tabel 2,080 berada pada daerah penerimaan dan menunjukkan nilai sig 0,982 lebih besar 0,05. Maka Ho diterima dan Ha ditolak yaitu profitabilitas tidak berpengaruh terhadap manajemen laba .

Profitabilitas diproksi dengan ROA, tidak berpengaruhnya ROA diduga karena investor cenderung mengabaikan informasi ROA yang ada secara makasimal sehingga manajemen pun menjadi tidak termotivasi melakukan manajemen laba melalui variabel profitabilitas. Hasil Penelitian ini sejalan dengan penelitian yang dilakukan oleh Noviana dan Yuyetta (2011) dimana hasil penelitiannya menunjukkan bahwa variabel profitabilitas (ROA) tidak berpengaruh signifikan terhadap manajemen laba.

\section{Pengaruh Resiko Keuangan terhadap Manajemen Laba}

Pada Tabel 6. hasil uji parsial secara keseluruhan yaitu tahun 2013-2017, pada variabel independen resiko keuangan didapat $\mathrm{t}$ hitung sebesar 0,157 lebih kecil dari $\mathrm{t}$ tabel 2,080 berada pada daerah penerimaan dan menunjukkan nilai sig 0,877 lebih besar 0,05. Maka Ho diterima dan Ha ditolak yaitu resiko keuangan tidak berpengaruh terhadap manajemen laba .

Hal ini dapat terjadi kemungkinan dikarenakan kebijakan hutang yang ketat sehingga perusahaan sulit untuk memperoleh kredit dan manajer cenderung tidak melakukan manajemen laba. Kemungkinan lain dikarenakan resiko keuangan tidak menjadi pertimbangan manajemen dalam melakukan manajemen laba. Hal tersebut sejalan dengan penelitian terdahulu yang dilakukan oleh Herni dan Susanto (2008) dan juga penelitian Andreas, Djumilah, dan Salim (2008) yang menyatakan resiko keuangan tidak berpengaruh signifikan terhadap manajemen laba. 


\section{Pengaruh Pertumbuhan Perusahaan terhadap Manajemen Laba}

Pada Tabel 6. hasil uji parsial secara keseluruhan yaitu tahun 2013-2017, pada variabel independen pertumbuhan perusahaan didapat $\mathrm{t}$ hitung sebesar -0,525 lebih kecil dari $\mathrm{t}$ tabel 2,080, berada pada daerah peneriman menujukkan nilai sig 0,605 lebih besar 0,05. Maka Ho diterima dan Ha ditolak yaitu pertumbuhan perusahaan tidak berpengaruh dan tidak signifikan terhadap manajemen laba.

Hal ini menunjukkan semakin tinggi atau semakin rendah pertumbuhan perusahaan maka tidak akan mempengaruhi manajemen laba. Hasil ini selaras dengan penelitian Nahar dan Erawati (2017) yang menyatakan pertumbuhan perusahaan tidak berpengaruh signifikan terhadap manajemen laba.

\section{Pengaruh Profitabilitas, Resiko Keuangan dan Pertumbuhan Perusahaan terhadap Manajemen} Laba

Pengaruh Profitabilitas, resiko keuangan dan pertumbuhan perusahaan terhadap manajemen laba secara bersama-sama dapat diketahui dari hasil uji F. Nilai Fhitung sebesar 0,098 dan tingkat signifikan sebesar $0,960^{\mathrm{b}}$. Dapat disimpulkan bahwa nilai signifikan lebih kecil daripada 0,05 artinya seluruh variabel independen (profitabilitas, resiko keuangan dan pertumbuhan perusahaan) secara bersamasama tidak berpengaruh terhadap variabel dependen (manajemen laba) pada perusahaan Kosmetik dan Keperluan Rumah Tangga yang Terdaftar di BEI tahun 2013-2017.

Hasil ini selaras dengan penelitian yang dilakukan oleh Muhammadinah (2016) yang menyatakan bahwa secara bersama-sama variabel profitabilitas $\left(\mathrm{X}_{1}\right)$, resiko keuangan $\left(\mathrm{X}_{2}\right)$ dan pertumbuhan perusahaan $\left(\mathrm{X}_{3}\right)$ tidak berpengaruh signifikan terhadap variabel manajemen laba $(\mathrm{Y})$.

\section{KESIMPULAN}

Berdasarkan hasil penelitian secara keseluruhan dapat diambil kesimpulan sebagai berikut:

1. Variabel profitabilitas tidak berpengaruh signifikan terhadap variabel manajemen laba pada perusahaan Kosmetik dan Keperluan Rumah Tangga yang terdaftar di Bursa Efek Indonesia (BEI) tahun 2013-2017.

2. Variabel resiko keuangan tidak berpengaruh terhadap variabel manajemen laba pada perusahaan Kosmetik dan Keperluan Rumah Tangga yang terdaftar di Bursa Efek Indonesia (BEI) tahun 20132017.

3. Variabel pertumbuhan perusahaan tidak berpengaruh terhadap variabel manajemen laba pada perusahaan Kosmetik dan Keperluan Rumah Tangga yang terdaftar di Bursa Efek Indonesia (BEI) tahun 2013-2017.

4. Variabel profitabilitas, resiko keuangan dan pertumbuhan perusahaan terhadap manajemen laba secara bersama-sama tidak berpengaruh terhadap manajemen laba pada perusahaan Kosmetik dan Keperluan Rumah Tangga yang terdaftar di Bursa Efek Indonesia (BEI) tahun 2013-2017. 


\section{REFERENSI}

Agus, Sartono. 2011. Manajemen Keuangan Teori dan Aplikasi. Yogyakarta: BPFE.

Anshori, Ema Rosyidah dan Wahidahwati. 2014. Analisis Faktor-faktor yang Mempengaruhi Manajemen Laba pada Perusahaan yang Terdaftar di BEI. Jurnal Ilmu dan Riset Akuntansi. Vol. 3 No. 11.

Andreas, Zain, Djumilah, dan Ubud Salim. 2008. Pengaruh Tata Kelola Korporasi, Pengungkapan Koeporasi, dan Risiko Keuangan terhadap Manajemen Laba dan Kinerja Korporasi. Eksekutif Vol. 5. Edisi Khusus. Hal: 90-107.

Fatmasari, Sofia. 2016. Pengaruh Profitabilitas dan Leverage terhadap Manajemen Laba. Artikel Ilmiah. Sekolah Tinggi Ilmu Ekonomi. Perbanas.

Fricilia, dan Lukman, H. 2015. Analisis Faktor-Faktor yang Mempengaruhi Praktik Manajemen Laba pada Industri Perbankan di Indonesia. Jurnal Akuntansi. Vol. 19 No 1. Hal: 79-92.

Herni, dan Yulius Kurnia Susanto. 2008. Pengaruh Struktur Kepemilikan Publik, Praktek Pengelolaan Perusahaan, Jenis Industri, Ukuran Perusahaan, Profitabilitas dan Risiko Keuangan terhadap Manajemen Laba. Jurnal Ekonomi dan Bisnis Indonesia. Vol. 23 No. 3.

Izzati, Ameraningrum dan Intan Komala Sari. 2013. Pengaruh Good Corporate Goverance, Leverage, Growth, Kinerja Keuangan terhadap Manajemen Laba. Vol.5

Kasmir. 2016. Analisis Laporan Keuangan. Jakarta: Raja Grafindo Persada.

McNichols, M, F. 2000. Research Design Issues in Earnings Management Studies. Journal of Accounting and Public Polity. 19. Page: 313-345.

Muhammadinah. 2016. Pengaruh Profitabilitas, Resiko Keuangan, Ukuran Perusahaan, GROWTH, Struktur Kepemilikan Manajerian dan Dividen Payout Ratio terhadap Manaemen Laba pada perusahaan Sektor Perbankan yang terdaftar di BEI. Vol. 2 No. 1.

Nahar, Mahfudzotun dan Taguh Erawati. 2017. Pengaruh NPM, FDR, Komite, Audit, Pertumbuhan Perusahaan, Leverage dan Size terhadap Manajemen Laba. Akuntansi Dewantara. Vol. 1 No. 1.

Novianus. 2016. Hubungan antara Ukuran Perusahaan, Leverage, Profitabilitas dengan Manajemen Laba. Skripsi. Universitas Sanata Daharma. Yogyakarta

Riyanto. 2011. Dasar-dasar Pembelanjaan Perusahaan. Yogyakata: BPFE.

Scott, William R. 2015. Financial Accounting Theory. $5^{\text {th }}$ Edition. Canada Prentice Hall.

Widyaningdyah, Utari A. 2011. Analisis Faktor-faktor yang Berpengaruh terhadap Manajemen Laba pada Perusahaan Go Public di Indonesia. Jurnal Akuntansi dan Keuangan. Vol. 3 No.2. 